\title{
PELAKSANAAN CUCI TANGAN PAKAI SABUN (TANTANGAN DAN PELUANG) SEBAGAI UPAYA KESEHATAN SEKOLAH DI SEKOLAH DASAR NEGERI KECAMATAN BOGOR UTARA KOTA BOGOR
}

\section{Implementation of Handwashing with Soap (Challenges and Opportunities) as A School Health Effort of Elementary School, Bogor Utara District, Bogor City}

\author{
Kenti Friskarini ${ }^{1}$, Totih Ratna Sundari ${ }^{1}$ \\ ${ }^{1}$ Badan Penelitian Dan Pengembangan Kesehatan, Kementerian Kesehatan RI \\ Email: friskarini@yahoo.com
}

Diterima: 2 April 2020; Direvisi: 28 Mei 2020; Disetujui: 25 Juni 2020

\begin{abstract}
Awareness of running Clean and Healthy Behavior (PHBS) in elementary school in general is still lacking. One part of PHBS is Handwashing with Soap (CTPS) which has an important impact on health. This paper explores the challenges and opportunities for implementing this program in elementary schools in Bogor from officers at schools, puskesmas, and health offices in 2018. Data were obtained by in-depth interviews with informants who was chosen by purposive sampling from the health office, education office, school principals and teachers from 5 selected schools. The results showed this activity was not yet a priority in the program, marking that health promotion was not yet maximally carried out at the policy holder level. Even though the elementary school which was the location of the study did not have a problem in providing facilities for washing hands, but not all could provide soap to get the maximum effect. This shows that the cooperation of various parties has not been optimal to support the success of this activity. As a suggestion, besides requiring support from various parties,it should be complemented by health promotions for students and the whole school environment so healthy behavior can be achieved.
\end{abstract}

Keywords: Handwashing, healthy behavior, health promotion

\begin{abstract}
ABSTRAK
Kesadaran menjalankan Perilaku Hidup Bersih dan Sehat (PHBS) di sekolah dasar (SD) pada umumnya masih kurang. Salah satu bagian dari PHBS adalah Perilaku Cuci Tangan Pakai Sabun (CTPS) yang memiliki dampak penting untuk kesehatan. Tulisan ini mengangkat tantangan dan peluang pelaksanaan CTPS pada SD di kota Bogor dari pihak sekolah, puskesmas dan dinas kesehatan pada tahun 2018. Desain penelitian adalah survey potong lintang dengan pemilihan sampel secara purposive. Data kualitatif didapatkan dengan wawancara mendalam kepada informan dari dinas kesehatan, dinas pendidikan, kepala sekolah dan guru dari 5 sekolah yang terpilih di Kecamatan Bogor Utara. Hasil penelitian menunjukkan kegiatan ini belum menjadi prioritas dalam program, menandai belum maksimalnya promosi kesehatan dilakukan di tingkat pemegang kebijakan. Walau secara keseluruhan SD yang menjadi lokasi penelitian tidak memiliki masalah dalam penyediaan sarana mencuci tangan, namun tidak semua dapat menyediakan sabun sehingga mempengaruhi hasil maksimal CTPS. Hal tersebut menunjukkan belum maksimalnya kerjasama berbagai pihak untuk mendukung keberhasilan kegiatan ini. Sebagai saran, CTPS selain memerlukan dukungan dari berbagai pihak, seharusnya dilengkapi dengan promosi kesehatan kepada para siswa, dan seluruh lingkungan sekolah sehingga terwujud perilaku yang baik dan sehat.
\end{abstract}

Kata kunci: CTPS, perilaku kesehatan, promosi kesehatan

\section{PENDAHULUAN}

Semua anak Indonesia berhak untuk mendapatkan akses pada lingkungan yang aman, bersih dan sehat di sekolah. Sanitasi sekolah termasuk ketersediaan akses merupakan langkah awal mewujudkan lingkungan belajar yang sehat yang aman, bersih dan sehat. Jika kesadaran untuk menjalankan Perilaku Hidup Bersih dan Sehat (PHBS) di sekolah masih kurang, maka sekolah dapat menjadi sumber penyebaran 
penyakit menular seperti diare dan pneumonia yang penularannya kebanyakan karena tangan yang terkontaminasi dengan organisme.

Penyakit diare ini menjadi penyebab utama kematian sekitar 1,7 juta anak di dunia setiap tahunnya (UNICEF, 2013) dan berdasarkan data dari WHO dalam Global Health Observatory tahun 2016 diketahui bahwa diare masih menjadi penyebab penting kematian sekitar 600.000 balita setiap bulannya di seluruh dunia (Wolf, Paul R. Hunter, et al., 2018). Di Indonesia sendiri, berdasarkan data Riskesdas tahun 2014, diare merupakan penyebab kematian keempat pada semua golongan umur (13,2\%), sedangkan pada Riskesdas 2017 diketahui bahwa prevalensi diare berdasarkan diagnosis dari tenaga kesehatan adalah sebesar 6,8\%, sedangkan untuk Provinsi Jawa Barat adalah sebesar 7,43\%. Banyak dari kematian ini dapat dicegah dengan mencuci tangan memakai sabun (World Health Organization, 2013)

Sebuah penelitian berjudul Effect of Washing Hands With Soap on a Diarrhoea Risk in The Community: A Systematic Review meneliti tentang dampak cuci tangan terhadap penyakit diare. Terdapat dua kesimpulan dari penelitian tersebut. Pertama mencuci tangan dapat mengurangi resiko diare sekitar 42-47 persen; Kedua menyuarakan kebiasaan cuci tangan dapat membantu menyelamatkan kurang lebih sekitar satu juta jiwa. Studi tersebut menunjukkan bahwa cuci tangan merupakan hal yang paling sederhana, tetapi sangat bermanfaat untuk dilakukan demi mengurangi infeksi penyakit (Curtis and Cairncross, 2003). Namun demikian dari hasil penelitian pada tahun 2014, diperkirakan hanya $19 \%$ populasi dunia yang mencuci tangan dengan sabun setelah buang air besar. (Freeman et al., 2014). Untuk Indonesia, berdasarkan data Riskesdas tahun 2017 diketahui bahwa masyarakat yang memiliki perilaku mencuci tangan dengan benar baru mencapai $49,8 \%$.

Dari hasil beberapa penelitian di sekolah diketahui beberapa faktor yang mempengaruhi pelaksanaan CTPS. Dalam penelitian yang dilakukan pada anak sekolah dasar di Jember diketahui bahwa hubungan antara perilaku cuci tangan dan insiden diare menunjukkan hubungan yang signifikan, dan keberhasilan kegiatan cuci tangan pakai sabun bukan hanya ditunjang oleh perilaku cuci tangan saja, namun juga oleh adanya sarana dan prasarana yang diperlukan dalam menjaga keberlangsungan kegiatan cuci tangan. (Purwandari, Ardiana and Wantiyah, 2015). Dalam laporan penelitian di Lampung Selatan diketahui bahwa dalam analisis bivariat, variabel yang mempunyai hubungan bermakna terhadap perilaku CTPS yaitu nilai-nilai, peran guru dan peran teman-teman sekolah (Murwanto, 2017).

Jika melihat dari profil sanitasi sekolah Indonesia tahun 2017, persoalan yang terkait dengan kesadaran untuk perilaku CTPS anak sekolah termasuk di antaranya adalah tersedianya akses terhadap sarana serta air yang layak dan cukup untuk pelaksanaannya. Jenjang SD menjadi jenjang yang rendah dalam akses terhadap sarana cuci tangan. Sekitar $34,9 \%$ SD di Indonesia tidak memiliki sarana cuci tangan. Papua menjadi provinsi yang paling banyak sekolah dasarnya tidak memiliki tempat cuci tangan $(68,6 \%)$, sedangkan untuk wilayah Jawa Barat sebesar 42,28\% sekolah dasarnya tidak memiliki sarana cuci tangan. Untuk tersedianya air bersih yang layak dan cukup, secara nasional pada tingkat SD baru mencapai $64,76 \%$, terendah di Kalimantan Utara (30.43\%), sedangkan Jawa Barat sebesar 71,42\%. (Kementerian Pendidikan dan Kebudayaan, 2017).

Situasi ini tentu sangat mengkhawatirkan, karena pembiasaan untuk melakukan Perilaku Hidup Bersih dan Sehat (PHBS) sudah sepatutnya dimulai sejak dini, dan sekolah yang memiliki sarana yang memadai untuk mencuci tangan merupakan tempat yang tepat untuk melakukan hal tersebut, seperti penelitian yang dilakukan kota Padang (Lina, 2016), kota Malang (Susilowati, 2017) dan hal ini juga berlaku di India dengan adanya kampanye kesehatan di sekolah pada tahun 2018 (Lewis et al., 2018).

Melihat pentingnya program CTPS yang terkesan sederhana namun ternyata memiliki dampak yang penting untuk kesehatan, maka tulisan ini mengangkat tantangan dan peluang pelaksanaan CTPS 
dari pihak sekolah, puskesmas dan dinas kesehatan.

\section{BAHAN DAN CARA}

Tulisan ini berdasarkan pada penelitian deskriptif dengan tujuan utama untuk membuat gambaran tentang suatu keadaan secara obyektif dan merupakan bagian dari Penelitian Gambaran Implementasi CTPS pada Siswa Sekolah Dasar di Kota Bogor pada tahun 2018. Berdasarkan aspek pengumpulan data, merupakan penelitian observasional karena hanya dilakukan melalui pengamatan secara langsung maupun tidak langsung tanpa ada perlakuan atau intervensi. Desain penelitian adalah survey potong lintang (cross sectional). Data kualitatif didapatkan dengan wawancara mendalam. Dalam tulisan ini mengangkat tentang hasil dari analisa data kualitatif yang sudah dilakukan dalam penelitian.

$\begin{array}{llr}\text { Untuk } & \text { mendapatkan } & \text { deskripsi } \\ \text { pelaksanaan program } & \text { CTPS dilakukan } \\ \text { multistage random sampling dengan }\end{array}$ menentukan satu kecamatan sebagai area penelitian berdasarkan jumlah kejadian diare tahun 2015 yang tertinggi di Kota Bogor (Profil Dinas Kesehatan Kota Bogor, 2016). Kasus diare tertinggi tahun 2015 terdapat di kecamatan Bogor Utara, sehingga terpilih sebagai area sampel penelitian. Setelah itu dipilih 5 sekolah dasar sebagai area penelitian dari 36 sekolah dasar negeri yang sudah melaksanakan sosialisasi program cuci tangan pakai sabun-yaitu : SD Negeri Kawung Luwuk, SD Negeri Cimahpar 1, SD Negeri Bantarjati 5, SD Negeri Sindang Sari, dan SD Negeri Cibuluh 1. Penentuan responden yang disebut sebagai narasumber atau informan dilakukan secara purposive sampling. Kecukupan informan bukan didasarkan jumlahnya, namun didasarkan kecukupan informasi yang bisa didapatkan dari informan. Hal ini sesuai dengan rangkuman yang dilakukan oleh Palinkas bahwa menurut teori dari Patton pada tahun 2002, teknik pengambilan sampel ini digunakan secara luas dalam penelitian kualitatif untuk mengidentifikasi dan mendapatkan informasi yang kaya dari sumber informasi yang terbatas, selain itu,
Creswell dalam bukunya yang berjudul Designing and conducting mixed method research pada tahun 2011 juga menyampaikan teknik ini mengidentifikasi dan memilih individu atau kelompok yang memiliki pengetahuan atau pengalaman dari yang akan diteliti. (Palinkas et al., 2016).

Sebagai informan atau narasumber dalam pendekatan kualitatif ini terdiri dari penanggung jawab program CTPS yaitu Bidang Kesehatan Masyarakat dan Promosi Kesehatan di Dinas Kesehatan Kota Bogor, penanggung jawab program CTPS di Puskesmas Kota Bogor, kepala sekolah, dan perwakilan satu orang guru dari masingmasing sekolah yang menjadi tempat penelitian. Kriteria inklusi dalam penelitian ini adalah sekolah dasar negeri yang sudah mengikuti sosialisasi program CTPS, sedangkan kriteria eksklusi adalah sekolah dasar negeri adalah yang tidak bersedia berpartisipasi menjadi tempat penelitian. Analisis data secara kualitatif dilakukan sesuai dengan referensi, dilakukan secara manual dengan tahapan pembuatan transkrip wawancara, penyusunan matrik dan penarikan pola dan penyimpulan berdasarkan temuan (Kusumawardani et al., 2015).

\section{Etik Penelitian}

Penelitian ini menggunakan metode wawancara mendalam dan survei kepada siswa/siswi sekolah dasar, sehingga diperlukan pertimbangan etik penelitian. Persetujuan etik dimintakan kepada Komisi Etik Badan Penelitian dan Pengembangan Kesehatan Kementerian Kesehatan RI dengan nomor LB.02.01/2/KE.243/2018.

\section{HASIL}

Dalam penelitian ini dilakukan wawancara mendalam yang dilakukan kepada staf dari Dinas Kesehatan Kota Bogor, Puskesmas Bogor Utara, dan Puskesmas Tegal Gundil, serta kepala sekolah dari lima sekolah yang terpilih dalam penelitian. Informasi yang dikumpulkan adalah mengenai pengetahuan informan, perencanaan yang terkait serta pelaksanaan dan hambatan yang ditemui dalam pelaksanaan Program CTPS. Informasi 
tentang hal-hal tersebut diperlukan untuk mengetahui bagaimana dukungan dari pihak terkait dengan pelaksanaan program ini.

\section{Pengetahuan tentang pelaksanaan CTPS}

Hasil wawancara dengan beberapa pihak yang terkait menunjukkan bahwa CTPS bukan sesuatu yang asing bahkan sudah lama dilakukan. Semua pihak memiliki peran dalam pelaksanaan CTPS, seperti petugas kesehatan di Dinas Kesehatan Kota Bogor mengetahui bahwa CTPS termasuk dalam program PHBS (Perilaku Hidup Bersih dan Sehat) di sekolah. Sebagai pelaksana utama dalam program CTPS di sekolah adalah petugas promosi kesehatan dan masuk melalui program Upaya Kesehatan Sekolah (UKS). Sebagai mitra dalam pelaksanaan program ini, dinas pendidikan menyatakan mengetahui manfaat CTPS dan melakukan kolaborasi dengan pihak terkait dan hal ini didukung juga oleh pihak sekolah yang diwakili oleh kepala sekolah dan guru. Mereka menyatakan bahwa CTPS merupakan program yang sudah lama ada dan siswa selalu diberikan penyuluhan tentang cuci tangan itu sendiri.

Dalam pelaksanaan program CTPS, dinas kesehatan menginstruksikan petugas promkes di puskesmas memberikan penyuluhan sesuai dengan masalah dan data, termasuk tentang diare yang mungkin disebabkan karena perilaku cuci tangan dan sebagainya. Hal ini dapat diketahui dari pernyataan berikut :

“... CTPS termasuk salah satu kegiatan yang memang sering temen- temen lakukan untuk penyuluhan di wilayah. Karena kalau kami dinas mungkin kami melakukan penyuluhannya tidak intensif seperti temen- temen di puskesmas. Kemudian CTPS sendiri termasuk salah satu indikator di PHBS sekolah, hampir di seтua tatanan PHBS. PHBS rumah tangga ada, PHBS tempat kerja ada, PHBS sekolah ada, PHBS tempat- tempat umum ada, dan PHBS untuk di sarana tempat ibadah juga masuk, jadi semua indikator PHBS itu salah satunya adalah cuci tangan pakai sabun dan air. Kemudian yang kami lakukan biasanya di level kota kami meminta menginstruksikan temen- temen memberikan penyuluhan sesuai dengan masalahnya. Karena kan yang mengetahui data mengenai penyakit dan sebagainya adalah temen- temen di wilayah. Jadi kami selalu menginformasikan penyuluhan berdasarkan data. Jadi kalau memang di situ permasalahannya adalah misalkan nih tingginya penyakit diare yang mungkin disebabkan karena perilaku cuci tangan dan sebagainya, ya itu adalah tugas dari temen- temen untuk memberikan informasi kepada masyarakat..."(SR, Dinas Kesehatan)

Menurut informan dari seksi kesehatan keluarga, CTPS untuk dapat masuk ke sekolah melewati program UKS (Usaha Kesehatan Sekolah). Menurut informan, seluruh sekolah di Kota Bogor sudah melaksanakan program CTPS melalui program UKS. Dalam program UKS terdapat Trias. Salah satu trias tersebut adalah pendidikan kesehatan. Dalam pendidikan kesehatan itu memberikan pengetahuan kepada anak didik supaya melakukan perilaku hidup bersih dan sehat, salah satunya adalah cuci tangan pakai sabun. Hal ini dapat diketahui dari penuturan informan berikut ini :

"Iya sebetulnya kalau CTPS tuh kan masuknya ke PHBS ya Perilaku Hidup Bersih Sehat. Kalau saya di sini di seksi kesehatan keluarga kita masuknya lewat program UKS, Usaha Kesehatan Sekolah di kota Bogor Insya Allah seluruh sekolah sudah melaksanakan. Kalau CTPS sih Insya Allah semua udah melaksanakan...kalau untuk CTPS sendiri sih semua sekolah sudah melaksanakan melalui program UKS."

Menurut informan dari dinas kesehatan tersebut, selain pakai sabun juga dengan menggunakan 7 langkah cuci tangan. Menurut informan untuk sekarang di SD sedang menggarap model sekolah sehat. Jadi kegiatan CTPS ini terintegrasi dalam KBM (Kegiatan Belajar Mengajar), seperti misalnya setiap kali mau makan, makan bersama, bawa bekal bersama, maka sebelumnya melakukan kegiatan cuci tangan bersama dulu; setelah makan sikat gigi bersama. Untuk kurikulum CTPS sudah masuk dalam pelajaran pendidikan jasmani. Dalam UKS tidak hanya mengetahui tetapi juga harus mengimplementasikan, harus 
membiasakan perilaku hidup bersih dan sehat.

Selain itu juga ada kegiatan literasi yaitu kegiatan membaca bersama muridmurid sebelum masuk jam pelajaran. Misalnya belajar jam 7, dari jam tujuh kurang seperempat anak-anak melakukan literasi. Literasi kesehatan diupayakan dilakukan minimal seminggu sekali dengan tema beragam. CTPS sendiri masuk ke dalam tema yang disampaikan dalam kegiatan literasi tersebut sehingga murid-murid dapat mempelajari tentang manfaat kegiatan tersebut.

Sebagai mitra dalam kegiatan untuk kesehatan anak sekolah, tentu tidak terlepas dari Dinas Pendidikan tingkat Kota Bogor. Sesuai pernyataan dari informan dinas pendidikan diketahui bahwa Program UKS Kota Bogor disusun bersama sesuai SKB 4 menteri tentang UKS. Untuk program cuci tangan tersebut termasuk dalam kegiatan dari Dinas Kesehatan. Berikut pernyataan dari informan tersebut :

“... Program UKS kota Bogor kan kita susun bareng-bareng dengan sesuai $S K B$ 4 menteri itu, dan itu ada dari kemenag, dinas kesehatan, kemudian dari kesra sama dari dinas pendidikan. Semenjak tahun 2017 UKS itu diambil alih oleh kesra, bukan Disdik lagi. Walaupun sekarang sekretariatnya oleh dinas pendidikan. Dan program itu berdasarkan DPA masingmasing, terutama dinas kesehatan, dinas pendidikan dengan kesra gitu kan. Contohnya misalkan ada dokter kecil itu kan punya dinkes, terus tadi program cuci tangan pakai sabun, program penjaringan dan sebagainya punya dinas kesehatan, kalau dari kesranya ada lomba sekolah sehat, di kita ada lomba sekolah bersih dan sehat seperti itu, lalu tentang sekolah berwawasan lingkungan, sekolah ramah anak, dari kita seperti itu, kita kolaborasikan dengan program UKS, karena tidak ada dana khusus buat UKS, makanya kita berkolaborasi seperti itu. Jadi, ada pun dana itu sifatnya hibah, jadi berjalan seperti itu aja dan Alhamdulillah kan efektif berhasil baik. Jadi kita melalui tangan ke tangan melalui pengawas $S D$, pengawas $T K$, sama-sama terjun ke sekolah-sekolah. Memberikan pemahaman bahwa UKS itu tidak hanya sekedar pojokan anak untuk pingsan dan sebagainya. Tapi UKS itu trias UKS yang disampaikan kepada mereka. Jadi biar mereka minimal berperilaku hidup bersih dan sehat di sekolah. Gitu aja programnya sih, tapi kalau mau lihat di bawah di sekretariat programnya lebih lengkap lah. Ini yang saya tahu..."(TK, Kasie Kesiswaan Dinas Pendidikan)

Pada tingkat puskesmas, petugas menjelaskan bahwa CTPS merupakan Cuci Tangan Pakai Sabun dengan air mengalir. Menurut informan program ini sudah berjalan sejak 2010 dan termasuk dalam indikator PHBS. Informan sebagai petugas puskesmas melakukan penyuluhan ke sekolah- sekolah juga dengan praktik langsung cuci tangan, yaitu dengan mengajarkan 7 langkah cuci tangan.

“...kalau di sekolah iya. Karena di sekolah itu semenjak saya masuk pun juga sudah ada pendataan. Makanya sudah ada pun program itu sudah ada, sudah berjalan di sekolah. Karena memang kita sudah, pas saya masuk pun memang sudah ada pendataan PHBS di sekolah juga. Dan memang indikatornya pun ada salah satunya adalah cuci tangan pake sabun..." (Y, PJ Promkes Puskesmas)

Begitu pula informan kepala puskesmas yang menyatakan bahwa puskesmas melakukan penyuluhan selain advokasi kepada pihak sekolah terutama untuk sarana dan prasarana untuk kegiatan cuci tangan di sekolah.

“...Jadi kalau dari program Cuci Tangan Pakai Sabun ini, yang kita garap memang untuk anak sekolah dasar di tambah TK untuk CTPS ini untuk anak SD dan TK. Kita adakan penyuluhan, kita lakukan advokasi ke pihak sekolah untuk membuatkan sarana dan prasarana untuk anak-anak bisa cuci tangan di sekolah pakai sabun terutama sehingga kemudian yang kita lakukan melatih memberikan contoh cara mencuci tangan pakai sabun dengan baik dan benar begitu..."(Sg, Kepala Sekolah)

Untuk tingkat sekolah, seluruh informan menyatakan bahwa CTPS merupakan program yang sudah lama ada dan siswa selalu diberikan penyuluhan tentang cuci tangan itu sendiri. Pengenalan 
pentingnya cuci tangan biasanya menggunakan lagu 7 langkah cuci tangan, begitu juga dengan program dokter kecil di sekolah. Hal ini dapat diketahui dari salah satu informasi dari penanggung jawab UKS di sekolah berikut ini :

“... Program CTPS ini sebetulnya kita sudah lakukan, dan sudah lama banget ya, sudah lama banget. Kita sosialisasikan bukan hanya kepada peserta didik tapi juga orang tua. Dimana orang tua, seperti kegiatan ini, olahraga bersama-sama ini ya, kita berikan kesempatan orangtua murid pada menyaksikan semua. Jadi peran serta orang tua murid pun membantu anak dalam kegiatan tersebut. Bukan hanya Cuci Tangan Pakai Sabun, tetapi juga sikat gigi massal. Itu dilakukan setelah melakukan olahraga. Tapi itu tergantung momennya ya, tergantung cuaca. Dulu kita masih punya itu tempat sikat gigi massal. Tapi karena ada perubahan fisik pembangunan sekolah, jadi paling sekali waktu gitu yah. Nah kalau program cuci tangan sendiri, kita sudah melaksanakannya dari dulu. Dari mulai caranya, menyanyikannya. Biasanya habis ini teh saya suka ngasih tau, " ayo, bagaimana ada 7 langkah cara cuci tangan, siapa yang bisa?". Kalau dokter kecil sudah tahu karena mereka kan sudah paham, sudah menerima materi ketika pelajaran ekskul. Ekskulnya tuh di hari Selasa. Jadi dia tahu program kita, yel- yel nya utuk anak dokter kecil, kemudian dari program cuci tangan itu kita sudah..." (A, PJ UKS sekolah)

Begitu pula yang disampaikan oleh salah satu informan kepala sekolah yang menyatakan bahwa kebersihan seperti mencuci tangan dapat menjadi penumbuhan karakter dari siswa untuk hidup bersih dan sehat. Berikut pernyataannya :

“...Di kami program pembiasaan hidup bersih dan sehat itu dalam rangka mereflesikan permendikbud nomor 21 tahun 2010. Bahwa siswa dalam rangka untuk memotivasi belajar, dalam arti kata suasananya bersih gitu, maka pembiasaanpembiasaan hidup sehat diantaranya cuci tangan tadi. Jadi penumbuhan karakter untuk hidup sehat dan bersih. Itu juga sudah di apa, diprogramkan maing- masing wali kelas.."(S, kepala sekolah)

\section{Perencanaan Terkait Program CTPS}

Sebagai awal dari pelaksanaan suatu kegiatan, tentu akan disusun perencanaan sebelumnya. Demikian pula dalam program CTPS. Pada tingkat dinas kesehatan, CTPS sendiri bukan termasuk program utama dalam kegiatan, namun merupakan bagian dari terlaksananya PHBS. Secara umum, kegiatan CTPS masuk dalam perencanaan kegiatan lain dan tidak secara khusus untuk direncanakan berjalan sendiri, baik di puskesmas maupun sekolah. Jadi masuk dalam perencanaan kegiatan untuk menanamkan kepada anak anak untuk hidup bersih dan sehat.

Dalam perencanaan kegiatan CTPS, Dinas kesehatan dalam hal ini berperan dalam memfasilitasi pelaksanaan program PHBS. MOU juga tidak ada dalam pelaksanaan UKS (salah satu kegiatan UKS adalah PHBS) di sekolah. Pernyataan ini menunjukkan bahwa CTPS bukan program utama namun merupakan kegiatan dalam PHBS. Begitu pula disampaikan oleh informan yang berasal dari seksi kesehatan keluarga, bahwa CTPS bukan program utama tetapi merupakan program pengembangan karena program utama biasanya adalah program menurunkan angka kematian ibu, atau angka kematian bayi. Hal ini dapat dilihat dari pernyataan informan berikut :

“.. Nah kalau disebut program utama sih gak ya rasanya. Kalau program utama kan kita biasanya untuk menurunkan angka kematian ibu, angka kematian bayi gitu ya. Tapi ya itu ya kalau UKS juga kan masuknya ke program pengembangan ya..."(S, informan dinas kesehatan)

"Sekarang di dalam germas pun juga kan belum khusus disebutkan CTPS, tapi di PHBS iya. Kalau di PHBS kan salah satunya cuci tangan pakai sabun. Kalau germas aja sekarang yang instruksi presiden cuma, kalau di Bogor nih 4 fokusnya. Cek kesehatan secara berkala, aktivitas fisik, makan buah sayur, sama tidak merokok. Kalau CTPS masuknya ke PHBS sih ya..."(E, informan dinas kesehatan)

Menurut wawancara dengan seksi Promosi Kesehatan Dinas Kesehatan Kota Bogor, sebenarnya memang tupoksi di promkes lebih fokus ke penyuluhan untuk 
mengubah perilaku. menanamkan perilaku, serta mengawasi perilaku. CTPS adalah mengenai perilaku sehingga harus meningkatkan kerjasama antar Organisasi Perangkat Daerah (OPD) juga dengan sekolah karena semua pihak harus ikut bertanggung jawab.

Pada tingkat puskesmas, perencanaan kegiatan CTPS secara khusus tidak ada tapi biasanya berhubungan dengan perencanaan kegiatan PHBS atau lainnya. Termasuk di dalamnya untuk melakukan sosialisasi kepada sekolah. Hal ini dapat diketahui dari pernyataan kepala puskesmas berikut :

“...kalau perencanaan khusus sih enggak, belum. Cuma masuknya ke pendataan kita PHBS terus programnya kalau ada ke sekolah kita selalu penyuluhannya itu CTPS di pelatihan dokcil juga yang pentingnya kita ngajar itu yang pertama, cuci tangan." (OK, Kepala Puskemas)

“... Kalau sosialisasi khusus cuci tangan itu kita usahakan menjelang hari cuci tangan itu kan ada tanggal berapa itu saya lupa kemarin. Nah nanti kita sosialisasi dulu ke gurunya, setelah itu nanti kita serentak cuci tangan bersama di sekolah kita bagi ada beberapa nanti. Memang tidak bisa mencapai semuanya. Kadang kita, tapi tiap tahun itu kita ganti- ganti tempatnya itu di situ, kalau untuk khusus cuci tangannya, tapi kalau sosialisasi tentang itu sendiri berbarengan dengan PHBS sekolah, kami kan suka mengundang kan kepala sekolah ataupun guru UKS untuk sosialisasi indikator PHBS sekolah itu. dan salah satunya dari indikator itu kan kita selalu menjelaskan, kita menjabarkan masingmasing salah satunya adalah PHBS itu..." $(Y$, PJ Promkes Puskesmas)

Secara umum, kegiatan CTPS masuk dalam perencanaan kegiatan lain di sekolah yang dilaksanakan bersamaan, yang pada intinya menanamkan kepada anak anak untuk hidup bersih dan sehat. Hal ini dapat dilihat dalam pernyataan guru sekolah yang merupakan penanggung jawab UKS berikut :

“... Rencana awal dari Program Gizi seimbang ya kalau disini, awalnya ikut pelatihan 3 orang, yaitu kepala SD dan 2 orang guru. Kemudian program Gizi
Seimbang disosialisasikan ke guru-guru kelas. Guru kelas memberikan penjelasan ke masing-masing kelasnya, agar muridmuridnya membawa makanan dari rumah tiap hari senin dan cuci tangan pakai sabun sebelum makan. Dan waktu pembagian raport, dilakukan sosialisasi kepada orang tua murid tentang gerakan sebelum makan harus cuci tangan terlebih dahulu..."

\section{Pelaksanaan CTPS}

Dalam pelaksanaan suatu kegiatan, tentu indikator terhadap keberhasilan suatu kegiatan sudah harus ditentukan sebelumnya, termasuk dalam kegiatan CTPS ini. Pada tingkat dinas kesehatan dari program promkes indikator yang digunakan adalah penyuluhan yang dilaksanakan secara keseluruhan, tidak dikhususkan untuk penyuluhan tentang CTPS. Menurut informan yang berasal dari bidang kesehatan keluarga yang dapat menjadi indikator adalah jumlah kasus diare pada anak sekolah. Hal ini dapat dilihat dari data jumlah kesakitan murid sehingga dapat dievaluasi apa penyebabnya.

"..kalau indikatornya kan kami hanya di penyuluhan ya ibu ya, melihat dari standar pelayanan minimal itu kan SPM, promkes mempunyai indikator adalah penyuluhan luar gedung itu sejumlah untuk menentukan angkanya adalah sejumlah posyandu yang ada di wilayah. Jadi itu untuk jumlah frekuensi tadi tidak hanya penyuluhan CTPS ya bu, jadi sетиa penyuluhan. Jadi kalau untuk outputnya mungkin akan lebih bagus lagi kalau ibu ke penyakit menular. Jadi ibu bisa lihat angka penyakit diarenya. Jadi kan penyakit diare, kecacingan dan sebagainya. Itu kalau outcomenya..." (E, Dinas kesehatan)

Untuk pernyataan dari informan lainnya dari dinas kesehatan kota dapat dilihat dari kutipan berikut :

“...Eeee, indikatornya jumlah anak. Kalau kita mau lihat sih dari jumlah anak yang sakit ya, misalnya diare kalau secara satu kota sih berarti itu jumlah kejadian angka kasus diare pada anak-anak usia sekolah misalnya gitu. .." 
“...Kalau di sekolah biasanya kita melihatnya dari absensi sakit. Makanya kalau di UKS itu, misalnya di, eee, harus punya data jumlah angka kesakitan murid misalnya. Jumlah yang sakitnya berapa orang, kemudian penyakitnya apa saja. Kalau misalnya ternyata oh banyak diare, jangan-jangan apakah karena kebiasaan CTPS nya atau kebiasaan jajannya. Nanti dievaluasi dianalisa, gitu.(SR, Dinas Kesehatan)"

Pada informan tingkat puskesmas, indikator keberhasilan pelaksanaan CTPS adalah jika kegiatan ini sudah menjadi rutinitas. Sudah tertanam dalam diri siswa bahwa cuci tangan adalah pembiasaan sehingga tidak terkena diare.

“...indikatornya ya. Hmm kalau berjalan dengan baik karena sudah menjadi rutinitas yang pasti dilakukan sebelum mulai bekerja cuci tangan menurut saya sudah termasuk berhasil ya jadi suatu kebiasaan untuk kebersihan cuci tangan. Kalau di sekolah mereka sudah terbiasa. Jadi pas mau makan, seperti kemarin kita pelatihan dokcil tuh di SD . sebelum kita memerintahkan ayo cuci tangan dulu, mereka udah terbiasa jadi pas waktu istirahat, langsung keluar dulu pada izin, bu cuci tangan dulu ya. Mereka udah pada tahu, langsung ke wastafel untuk cuci tangan terus kan udah disediakan sabun kan oleh sekolah. Jadi dengan dikasih penyuluhan tentang pentingnya cuci tangan biar kumannya gak nempel, biar gak sakit diare, mereka udah tertanam jadi ngerti. Tiap mau makan, tiap mau main mereka cuci tanga sendiri. Jadi secara kasat mata... ( $Y$, PJ Promkes Puskesmas)

Indikator keberhasilan kegiatan CTPS dengan adanya pembiasaan untuk melakukannya pada siswa juga disampaikan oleh informan yang merupakan kepala sekolah. Namun hal itu diharapkan tidak hanya dilakukan siswa di sekolah tetapi juga dikerjakan di rumah.

"Berhasil itu timbulnya kebiasaan siswa. Jadi ketika siswa udah membiasakan diri untuk cuci tangan, baik itu sebelum kegiatan. Bukan hanya sekedar mau makan dan minum, tapi mau belajar juga kita mah. Itu anggap lah berhasil, jadi harus seperti itu. jadi kalau anak sudah terbiasa itu tujuannya. Karena tujuan itu pembiasaan. Tapi tidak bisa mutlak dikatakan berhasil karena terpantau di sekolah, tidak tahu di rumah.(S, Kepala Sekolah)

Selain pada timbulnya kebiasaan untuk mencuci tangan, indikator keberhasilan adalah berkurangnya anak yang sakit diare. Walaupun tidak pernah diukur oleh pihak sekolah secara khusus, namun bagi pihak sekolah hal ini merupakan indikator keberhasilan. Berikut pernyataan dari salah seorang kepala sekolah :

“ Berkurangnya anak yang mempunyai penyakit diare. Sakit perut, alhamdulillah. Karena salah satu penyebab penyakit diare atau muntaber itu juga dari itu, pembiasaan anak. Kita kasih tahu, kalau mau cuci tangan itu manfaatnya untuk apa, diantaranya apa,diare, muntaber dan lainlain.(SU, Kepala Sekolah)

Pada tingkat sekolah, ketersediaan fasilitas merupakan hal yang penting agar kegiatan CTPS dapat berjalan dengan baik. Pada pelaksanaan penelitian, diketahui bahwa keseluruhan sekolah yang diteliti memiliki fasilitas cuci tangan, yaitu tersedia air dan wastafel. Sedangkan untuk sabun, tidak semua dapat menyediakan secara kontinu. Tentu saja jika ketersediaan sabun masih bermasalah akan mempengaruhi tujuan akhir dari kegiatan CTPS itu sendiri terutama dalam pencegahan penyebaran penyakit. Hal ini dapat dilihat dari penuturan informan yang berasal dari dinas kesehatan :

"Saya belum mastiin ya. Tapi kalau untuk pelaksanaannya sih, implementasinya sih saya rasa sudah. Kalau misalnya kita cek ke sekolah pun mereka, kita haruskan mereka punya tempat cuci tangan ya, tempat cuci tangan dengan air yang mengalir dan sabun gitu. Cuma memang kadang-kadang yang suka kendala ya, kendalanya untuk CTPS, S nya itu, Sabunnya. Jadi pada saat kita evaluasi pun ke sekolah, misalnya, ada sih tempat cuci tangannya ya gitu ya, alir mengalirnya ada, air bersihnya ada, kebiasaannya anak-anak cuci tangan, tapi sabunnya yang habis, gak ada. Alasannya mungkin kadang-kadang kan, ya soalnya itu sama anak-anak dimainin atau apa lah gitu ya namanya di sekolah gitu. Tapi kita selalu ingatkan supaya mereka tetep menyediakan 
sabun, karena memang cuci tangan harus pake sabun." (S, Dinas Kesehatan)

Menurut salah seorang kepala puskesmas, untuk sarana seperti wastafel untuk mencuci tangan, hampir semua sekolah sudah memiliki. Hal ini didapatkan bukan hanya dari bantuan pada pembangunan fisik di sekolah, namun juga dengan adanya bantuan dari pihak swasta. Berikut pernyataan kepala puskesmas tersebut.

“...Hampir 100\% sudah lengkap di sekolah-sekolah wilayah wilayah kami insya Allah sudah ada sarana dan prasarana untuk cuci tangan diantaranya wastafel dan Alhamdulillah jumlahnyapun ada yang lebih dari 5 bahkan ada yang lebih dari 10 wastafel karena mereka sudah kerjasama dengan sponsor hampir sетиа di sponsori...". (OK, Kepala Puskesmas)

Selain wastafel, kebutuhan air juga bukan menjadi masalah pada sekolah yang dikunjungi untuk penelitian ini. Namun pemenuhan sabun sebagai kelengkapan kegiatan CTPS ini masih menjadi masalah. Menurut informan dari pihak sekolah, sabun terlalu cepat habis karena siswa senang menggunakan berkali-kali. Ada pula yang menyebutkan bahwa tidak semua dapat menyediakan sabun karena anggaran yang tidak terlalu besar dalam penyediaanya.

“...Alhamdulillah dari kelas 1 sampai kelas 6, waktu itu kan wastafel nya hanya beberapa wastafel, sekarang diperbanyak, jadi anak- anak sudah terbiasa dengan mencuci tangan. Lagipula kebetulan itu si anak itu, si sabunnya sabunnya suka dimainkan. Memang sih anak tetep. Kadangkadang kalau udah disimpan, satu hari habis, satu hari habis.."

Begitu pula yang disampaikan oleh salah seorang guru yang menjadi penanggung jawab kegiatan UKS di sekolah. Masalah sabun sebagai bagian penting dari pelaksanaan kegiatan CTPS masih menjadi kendala. Mulai dari anggaran untuk pasokan sabun hingga pemeliharaan fasilitas.

“...Nah sabunnya sendiri itu karena kita dulu dari swasta ya dibantu, tapi sudah tidak. Untuk mengeluarkan anggaran dari sekolah pun paling hanya untuk alakadarnya satu tempat itu aja. Kalau pemeliharaan Alhamdulillah, kalau pemeliharaan nggak jadi masalah kalau pemeliharaan mah ya. Kita kan bisa untuk anggaran rumah tangga untuk di dapur itu sabun mah untuk membersihkan mah udah biasa. Hanya untuk sabun cuci tangannya itu, itu yang jadi masalah itu." (A, PJ UKS sekolah)

Masalah ketersediaan sabun ini juga disinggung oleh seorang kepala sekolah, karena ketika penelitian dilakukan diketahui bahwa sabun tidak disediakan di tempat cuci tangan. Tidak mudahnya mencari jalan keluar untuk masalah ini karena tidak diperkenankannya sekolah untuk mengajukan bantuan kepada pihak lain, termasuk peran serta orang tua siswa. Berikut pernyataan dari kepala sekolah yang bersangkutan.

"Iya betul sedang kosong ibu, jadi kita punten aja jadi sekolah itu sedang, dana belum turun sampai sekarang gitu. Kita juga mau ngomong sama orang tua juga kan masih ada masalah hal- hal yang pemungutan- pemungutan itu kan kita nggak boleh?. Kita sekarang sedang meredam bu. Meredam dulu, takutnya ada wartawan yang mau mengungkit, "aduh di SD ini ada pungutan- pungutan gitu kan”. Kan sekarang di seтиa sekolah sama, meredam supaya jangan sampaii terjadi gitu pungutanpungutan sebesar apapun gitu. jadi kita serba hati- hati menyikapinya" (M, Kepala Sekolah)

Namun ada pula informan yang merupakan kepala sekolah menyatakan bahwa untuk kelengkapan sarana kebersihan termasuk sabun merupakan hal yang dapat dicarikan solusi. Solusinya adalah dengan menyampaikan kebutuhan kepada komite sekolah. Komite dapat membantu berdasarkan musyawarah antara orang tua murid karena hal tersebut diperkenankan sesuai peraturan.

"Terkait penyediaan alat dan sarana kebersihan juga kita kerjasama dengan komite. Jadi komite ada komite sekolah, ada komite kelas. Biasanya komite kelas ini membantu apa- apa yang dibutuhkan oleh kelasnya itu sendiri. Termasuk penyediaan sabun, diantaraya itu juga. Ya sabun, ya alat- alat pel dan sebagainya di situ. Berdasarkan peraturan, bukan tidak diperkenankan. Artinya ketika kebutuhan itu dirasa ada, orang tua kemudian 
musyawarah, ada hasil pertemuan dengan wali kelasnya, membutuhkan ini ini ini yang dikeluarkan sekolah umpamanya sekian, kurangnya sekian, ya dibantu. " (S, Kepala Sekolah)

\section{PEMBAHASAN}

Mencuci tangan dengan air dan sabun merupakan langkah kecil untuk memiliki hidup sehat. Perilaku sederhana ini bisa melindungi kita dari penyakit seperti diare dan saluran pernapasan. Banyak penyakit infeksi dimulai dengan sentuhan dengan tangan yang terkontaminasi dengan organisme. Hal ini dapat terjadi setelah menggunakan toilet, batuk atau bersin, penanganan sampah dan menyentuh permukaan lain yang sudah terkontaminasi (Majorin et al., 2014).

Sanitasi sekolah juga merupakan salah satu prioritas pembangunan yang sesuai dengan Tujuan 4a Sustainable Development Goals (SDGs). Tujuan 4a adalah untuk pendidikan yang berkualitas yaitu "Membangun dan meningkatkan fasilitas pendidikan yang ramah anak, penyandang cacat, dan gender, serta memberikan lingkungan belajar yang aman, anti kekerasan, inklusif, dan efektif bagi semua". Lebih rinci lagi pada tujuan 4a1 dinyatakan "Proporsi sekolah dengan akses ke: (a) listrik, (b) internet untuk tujuan pengajaran, (c) komputer untuk tujuan pengajaran, (d) infrastruktur dan materi memadai bagi siswa difabel, (e) air minum layak, (f) fasilitas sanitasi dasar per jenis kelamin, (g) fasilitas cuci tangan". Sejalan dengan tujuan SDGs, maka sanitasi sekolah terdiri dari akses air, sanitasi, dan fasilitas cuci tangan. Selain itu, Peraturan Menteri Pendidikan Nasional Nomor 24 Tahun 2007, mencantumkan syarat ketersediaan jamban untuk siswa dan siswi pada setiap jenjang sekolah Perhatian pada kesehatan lingkungan sekolah, termasuk di dalamnya sanitasi sekolah merupakan amanat undang-undang, khususnya UU Kesehatan Nomor 36 Tahun 2009 tentang Kesehatan. Pasal 79 menegaskan bahwa "Kesehatan Sekolah diselenggarakan untuk meningkatkan kemampuan hidup peserta didik dalam lingkungan sehat sehingga peserta didik dapat belajar, tumbuh, dan berkembang secara harmonis dan setinggitingginya menjadi sumber daya manusia yang berkualitas." (Direktorat Jenderal Pendidikan Dasar dan Menengah, 2017).

Dokumen Core questions and indicators for monitoring WASH in Schools in the Sustainable Development Goals yang diterbitkan oleh UNICEF dan WHO tahun 2016, mendefinisikan akses pada sanitasi sekolah ke dalam empat tingkatan, yaitu, tidak tersedia akses, pelayanan terbatas, pelayanan dasar, dan pelayanan tingkat lanjut. Jenis akses itu sendiri terbagi menjadi tiga, yaitu akses pada sumber air minum layak dan tersedia sepanjang waktu, akses pada fasilitas sanitasi dasar yang layak dan terpisah, dan akses pada fasilitas cuci tangan dengan sabun dan air mengalir (World Health Organization, 2016).

Secara nasional, CTPS merupakan bagian dari gerakan PHBS yang kemudian diperbaharui dengan Gerakan Masyarakat Hidup Sehat (Germas) pada tahun 2017. Germas adalah sebuah gerakan yang bertujuan untuk memasyarakatkan budaya hidup sehat serta meninggalkan kebiasaan dan perilaku masyarakat yang kurang sehat. Aksi Germas ini juga diikuti dengan memasyarakatkan perilaku hidup bersih sehat dan dukungan untuk program infrastruktur dengan basis masyarakat.

Germas di sekolah dilakukan dengan mewujudkan PHBS di sekolah dengan memberdayakan siswa, guru dan masyarakat lingkungan sekolah. Sebagai bagian dalam program tersebut, lingkungan sekolah merupakan sasaran untuk mewujudkan kesehatan masyarakat secara keseluruhan. Sebuah sekolah dapat dikatakan menerapkan Sanitasi Sekolah yang baik apabila sekolah tersebut dapat memenuhi tiga aspek yang saling berkaitan satu dengan lainnya, yakni: 1) Sekolah memenuhi ketersediaan sarana dan prasarana sanitasi, terutama akses pada sarana air bersih yang aman dari pencemaran, sarana sanitasi (jamban) yang berfungsi dan terpisah antara siswa laki laki dan perempuan, serta fasilitas cuci tangan pakai sabun; 2) Sekolah melaksanakan kegiatan pembiasaan Perilaku Hidup Bersih dan Sehat (PHBS), seperti kegiatan Cuci Tangan Pakai Sabun (CTPS) secara rutin dan memastikan pelaksanaan Manajemen Kebersihan 
Menstruasi (MKM) secara konsisten; 3) Adanya dukungan manajemen sekolah untuk mengalokasikan biaya.

Terkait dengan hal tersebut dilakukan pengembangan Usaha Kesehatan Sekolah (UKS). UKS sendiri memiliki 3 pilar,yaitu Pendidikan Kesehatan, Pelayanan Kesehatan dan Pembinaan Lingkungan Sekolah Sehat. Program UKS dilaksanakan oleh Tim Pelaksana UKS yang ada di setiap sekolah termasuk jenjang Sekolah Dasar.

Hal ini sesuai dengan pernyataan dari informan dari Dinas Kesehatan Kota Bogor. CTPS sendiri merupakan kegiatan yang sosialisasinya sudah lama dilakukan kepada semua sekolah di wilayah Kota Bogor. CTPS disosialisasikan oleh semua puskesmas dan masuk ke dalam sekolah lewat UKS.UKS sendiri menurut informan yang bertugas di dinas pendidikan dijalankan sesuai dengan SKB 4 Menteri (Kementerian Pendidikan dan Kebudayaan, 2017)

Dalam sekolah, CTPS sudah masuk dalam Kegiatan Belajar Mengajar (KBM) terutama pelajaran pendidikan jasmani (Kementerian Kesehatan RI, 2018). Hal ini juga diterapkan di sekolah sekolah di Kota Bogor. Di Kota Bogor CTPS ini dikenal dengan nama kegiatan 7 Langkah Cuci Tangan selain itu juga adanya peringatan Hari Mencuci Tangan Sedunia yang juga merupakan kegiatan rutin tahunan yang dilakukan di Dinas Kesehatan Kota Bogor.

Sudah lamanya program ini berjalan menyebabkan pemegang kebijakan di tingkat kota dan kepala sekolah mengakui pernah mendengar dan mengetahui adanya dan pentingnya CTPS di sekolah-sekolah. Hal ini merupakan hal yang penting karena pengetahuan yang baik dari pemegang kebijakan termasuk guru berdampak baik terhadap pelaksanaan kebijakan yang dikeluarkan. Kenyataan ini dapat dilihat dari penelitian yang dilakukan di Kota Palangkaraya bahwa dengan pengetahuan yang baik warga sekolah telah menerapkan PHBS dalam kehidupan sehari-hari, lingkungan sekolah yang bersih dan sehat serta meningkatnya prestasi akademik siswa (Nurhalina, Suratno and Marchel, 2017) serta saran dari hasil penelitian di Kota Semarang bahwa para guru sebaiknya meningkatkan pengetahuan siswa mengenai cuci tangan pakai sabun dengan meningkatkan penyampaian informasi baik melalui pelajaran ataupun media- media visual yang menarik dan mudah dipahami oleh siswa (Kartika, Widagdo and Sugihantono, 2016).

Selain adanya pengetahuan, perencanaan terhadap suatu kegiatan juga merupakan hal yang penting agar pelaksanaannya dapat berjalan dengan baik. Pada tingkat dinas kesehatan, CTPS sendiri ternyata bukan termasuk program utama dalam kegiatan, namun merupakan bagian dari terlaksananya PHBS. Dinas kesehatan dalam hal ini berperan dalam memfasilitasi pelaksanaan program PHBS. MOU antara dinas kesehatan maupun sekolah juga tidak ada dalam pelaksanaan UKS (salah satu kegiatan UKS adalah PHBS) di sekolah. Begitu pula yang disampaikan oleh informan yang berasal dari seksi kesehatan keluarga dinas kesehatan kota, bahwa CTPS bukan program utama tetapi merupakan program pengembangan karena program utama biasanya adalah program menurunkan angka kematian ibu, atau angka kematian bayi.

Pada tingkat puskesmas, perencanaan kegiatan CTPS secara khusus tidak ada tapi biasanya berhubungan dengan perencanaan kegiatan PHBS atau lainnya. Termasuk di dalamnya untuk melakukan sosialisasi kepada sekolah. Begitu pula dalam sekolah, CTPS bukanlah kegiatan yang khusus direncanakan berlangsung di sekolah.

Jika melihat dari pernyataan informan diketahui bahwa kegiatan CTPS masih menjadi kegiatan yang tidak direncanakan khusus, dan disisipkan dalam kegiatan yang berhubungan dengan PHBS lainnya, atau kegiatan yang berkaitan dengan kesehatan, seperti pelaksanaan pelatihan dokter kecil di beberapa sekolah yang ada di Kota Bogor. Hal ini menunjukkan bahwa walaupun sudah merupakan kegiatan yang berlangsung lama namun CTPS belum dianggap suatu kebutuhan utama sehingga perlu dibuat perencanaan yang baik agar tercapai tujuannya. Hal ini yang ternyata juga ditemui dalam penelitian yang dilakukan di Semarang (Nurhayu et al., 2018). Dalam promosi kesehatan tentu hal ini bukanlah hal yang diinginkan, karena promosi kesehatan dimanapun tempatnya seharusnya dilakukan 
dengan perencanaan sehingga dapat mengidentifikasi dukungan dan masalah yang ada (Davies Wendy, 2013). Suatu intervensi dapat menjadikan suatu hal dapat berubah, namun tanpa perencanaan dan tujuan intervensi tidak dapat berjalan dengan baik. (Nutland and Cragg, 2015) .

Dalam pelaksanaannya, CTPS sendiri seharusnya memiliki indikator keberhasilan. Jika melihat pernyataan dari para informan ternyata indikator tersebut dapat berbeda-beda. Dari dinas kesehatan, indikator keberhasilan adalah adalah jumlah kasus diare pada anak sekolah. Hal ini dapat dilihat dari data jumlah kesakitan murid sehingga dapat dievaluasi apa penyebabnya. Informan yang merupakan kepala sekolah juga menyampaikan hal yang sama, walaupun tidak pernah melakukan pengukuran secara khusus dan biasanya berdasarkan absensi biasa. Cuci tangan menjadi kebiasaan para murid sebelum dan sesudah makan, juga kegiatan lain juga menjadi indikator keberhasilan kegiatan, namun karena pemantauan itu hanya bisa dilakukan di sekolah sehingga tidak mutlak dapat dikatakan berhasil.

Selain kedua indikator di atas, ketersediaan fasilitas merupakan hal yang penting agar kegiatan CTPS dapat berjalan dengan baik. Pada pelaksanaan penelitian, diketahui bahwa keseluruhan sekolah yang diteliti memiliki fasilitas cuci tangan, yaitu ketersediaan air dan wastafel. Sedangkan untuk sabun, tidak semua dapat menyediakan secara kontinu. Kendala yang ditemui untuk masalah penyediaan sabun ini mulai dari tidak adanya anggaran untuk pasokan sabun hingga pemeliharaan fasilitas cuci tangan. Tidak mudahnya mencari jalan keluar untuk masalah ini karena tidak diperkenankannya sekolah untuk mengajukan bantuan kepada pihak lain, termasuk peran serta orang tua siswa. Tentu saja jika ketersediaan sabun masih bermasalah tentu mempengaruhi tujuan akhir dari kegiatan CTPS itu sendiri terutama dalam pencegahan penyebaran penyakit.

Ada bukti bahwa tidak adanya sabun pada fasilitas cuci tangan di sekolah merupakan masalah di banyak negara. Seperti yang sudah dirangkum oleh van Maanen dan kawan-kawan (Maanen et al.,
2016), bahwa studi yang dilakukan di beberapa negara menunjukkan bahwa inisasi mencuci tangan dengan sabun berhubungan dengan absensi siswa, misalnya di Denmark dan Spanyol yang memiliki kebiasaan siswa mencuci tangan paling tidak tiga kali sehari si sekolah mengurangi absensi siswa karena penyakit infeksi sebesar 30-37\%.

Jika melihat hasil penelitian dapat diketahui bahwa peluang dalam pelaksanaan CTPS di sekolah dimulai dari sudah tidak asingnya program tersebut pada seluruh pihak yang diwawancarai. Bahkan kegiatan CTPS dianggap dapat menjadi salah satu faktor yang mengubah karakter siswa untuk memiliki perilaku hidup bersih dan sehat. Namun sebagai tantangan adalah masih ditempatkannya CTPS sebagai program sisipan atau tambahan dalam kegiatan yang dilakukan, hal ini menandakan bahwa CTPS belum dianggap sebagai kegiatan yang penting atau utama. Hal ini juga yang mempengaruhi penyediaan kelengkapan kegiatan CTPS seperti ketersediaan sabun dan wastafel yang memenuhi syarat sesuai jumlah siswa, sedangkan untuk air tidak ditemui masalah dalam akses dan jumlah karena bertempat di kota Bogor. Selain itu tantangan yang lain adalah tidak adanya indikator keberhasilan kegiatan CTPS yang seragam dari semua pihak. Misalnya saja masih disebutkan bahwa turunnya angka diare dianggap sebagai indikator keberhasilan, namun sesungguhnya masih sangat banyak faktor yang mempengaruhi keberhasilan penurunan diare, dan CTPS adalah salah satu faktor pendorongnya.

Melihat dari hasil penelitian tersebut dapat diketahui bahwa masih banyak pekerjaan promosi yang diperlukan untuk meningkatkan pelaksanaan CTPS ini di negara-negara dengan beban penyakit tinggi seperti Indonesia. Promosi kesehatan yang seharusnya tetap dilakukan oleh seluruh pihak yang terkait dengan pelaksanaan kegiatan sederhana ini sehingga masalah seperti pemenuhan kebutuhan dasar seperti tersedianya sabun untuk mencuci tangan, fasilitas cuci tangan yang memadai, bahkan ketersediaan air yang kontinu bukan menjadi masalah dan bukan hanya tanggung jawab pihak sekolah, juga bukan beban yang harus diselesaikan pihak kesehatan. Namun 
kerjasama instansi-instansi pemerintah termasuk dengan masyarakat adalah syarat berhasilnya upaya peningkatan perilaku sanitasi masyarakat di suatu wilayah.

Sayangnya, membuat mereka bekerjasama tidaklah mudah. Tiap instansi sudah disibukkan dengan tugas pokoknya masing-masing. Kerjasama antar instansi sebenarnya dapat ditingkatkan asalkan ada komunikasi yang lebih baik di antara mereka. Pertemuan-pertemuan harus diadakan agar mereka dapat saling berbagi informasi dan bertukar pikiran. Dari situ mereka akan mencoba melakukan sinkronisasi kegiatankegiatannya sebelum akhirnya melihat peluang kerjasama sesuai dengan Panduan Penyusunan Strategi Sanitasi Sekolah yang dimaksudkan sebagai salah satu upaya mewujudkan amanat UU No. 36/2009 tentang Kesehatan (Bappenas, Pokja AMPL and UNICEF, 2017). Banyak contoh yang dapat dilakukan agar kegiatan sederhana ini namun memiliki dampak besar dapat dijalankan dengan memulai perencanaan disertai dengan produk kebijakan dan regulasi sebagai dasar pemberian prioritas pada pembiayaan pembangunan. Salah satunya dapat dilihat dari yang dilakukan oleh beberapa pihak pada laporan yang dituliskan oleh kelompok kerja AMPL (Air Minum dan Penyehatan Lingkungan) dalam mendorong keberhasilan pelaksanaan program WASH (Water, Sanitation and Hygiene) (Kelompok Kerja AMPL, 2019). Dalam laporan tersebut, terlihat inisiasi dari pimpinan daerah setelah mendapatkan advokasi yang baik termasuk dari fasilitator sehingga mendorong diadakannya kebijakan yang dapat mendorong keberhasilan pelaksanaan program WASH, di mana CTPS sendiri merupakan bagian yang penting dalam program tersebut.

\section{KESIMPULAN DAN SARAN}

\section{Kesimpulan}

Sekolah seharusnya merupakan tempat untuk tumbuh kembangnya anak-anak dan remaja yang sehat. Kebanyakan waktu mereka dihabiskan di sekolah sehingga perilaku sehat dapat dibimbing sehingga menjadi karakter dalam hidupnya, termasuk kebiasaan untuk mencuci tangan dengan sabun. Dalam penelitian didapatkan hasil bahwa sebagai peluang adalah SD yang menjadi lokasi penelitian tidak memiliki masalah dalam penyediaan air untuk sarana mencuci tangan dan sudah dikenalnya program ini sejak lama oleh seluruh pihak. Namun sebagai tantangan dalam kegiatan ini adalah belum dijadikannya prioritas dalam program, dan karena sudah dianggap biasa maka perhatian tidak terlalu diberikan terhadap kegiatan ini, hal ini menandai belum maksimalnya promosi kesehatan dilakukan di tingkat pemegang kebijakan. Selain itu kebiasaan sehari-hari mencuci tangan dengan sabun pada murid sehingga menjadi karakter murid belum menjadi salah satu ukuran keberhasilan penanaman promosi kesehatan. Tantangan lainnya adalah penyediaan sabun karena tidak semua SD dapat menyediakan dengan beberapa sebab sehingga mempengaruhi hasil maksimal dalam kegiatan mencuci tangan dengan sabun. Masih adanya masalah tersebut menunjukkan belum maksimalnya kerjasama dari berbagi pihak untuk mendukung keberhasilan kegiatan ini.

\section{Saran}

Pelaksanaan CTPS sebagai dasar kegiatan kesehatan diri dan lingkungan di sekolah, memerlukan dukungan dari berbagai pihak. Kerjasama yang baik antara instansi yang terkait perlu lebih ditingkatkan. Penyediaan fasilitas mencuci tangan hingga penyediaan sabun seharusnya tidak dibebankan hanya kepada salah satu pihak, dan seharusnya juga dilengkapi dengan promosi kesehatan yang lebih baik tentang manfaat kegiatan kepada para siswa dan seluruh lingkungan sekolah sehingga terwujud perilaku yang baik dan sehat.

\section{UCAPAN TERIMAKASIH}

Ucapan terima kasih kami sampaikan kepada Kepala Badan Litbangkes, Kepala Puslitbang Upaya Kesehatan Masyarakat, dan ketua PPI Puslitbang Upaya Kesehatan Masyarakat, yang telah memberikan kepercayaan dalam pelaksanaan penelitian sehingga dapat menjadi sumber penulisan artikel ini. 


\section{DAFTAR PUSTAKA}

Bappenas, Pokja AMPL and UNICEF (2017) Panduan Penyusunan Dokumen Perencanaan Strategis Sanitasi Sekolah. Edited by A. Mardikanto, P. Sortaria, and R. Hendrawan. Jakarta, Indonesia: Kelompok Kerja AMPL.

Curtis, V. and Cairncross, S. (2003) 'Effect of washing hands with soap on diarrhoea risk in the community: A systematic review', Lancet Infectious Diseases, 3(5), pp. 275-281. doi: 10.1016/S1473-3099(03)00606-6.

Davies Wendy, M. M. (2013) Health promotion theory. 2nd edn. England: Open University Press.

Direktorat Jenderal Pendidikan Dasar dan Menengah (2017) Peta Jalan Sanitasi Sekolah Dalam Kerangka UKS. Jakarta: Direktorat Jenderal Pendidikan Dasar dan Menengah, Kementerian Pendidikan dan Kebudayaan.

Freeman, M. C. et al. (2014) 'Systematic review: Hygiene and health: Systematic review of handwashing practices worldwide and update of health effects', Tropical Medicine and International Health, 19(8), pp. 906-916. doi: 10.1111/tmi.12339.

Kartika, M., Widagdo, L. and Sugihantono, A. (2016) 'Faktor-Faktor Yang Berhubungan Dengan Perilaku Cuci Tangan Pakai Sabun Pada Siswa Sekolah Dasar Negeri Sambiroto 01 Kota Semarang', Jurnal Kesehatan Masyarakat (e-Journal), 4(5), pp. 339-346.

Kelompok Kerja AMPL (2019) 100\% Kerja untuk Kejar 100\%: Kumpulan Kisah WASH Program untuk Mendukung Tercapainya Universal Akses 2019. Edited by Aldy Mardikanto (BAPPENAS), P. S. (Pokja A. Nasional), and R. Hendrawan. Jakarta, Indonesia: Kelompok Kerja AMPL.

Kementerian Kesehatan RI (2018) Petunjuk teknis pelaksanaan sekolah / madrasah sehat. Jakarta: Kementrian Kesehatan RI.

Kementerian Pendidikan dan Kebudayaan (2017) Profil Sanitasi Sekolah. Jakarta, Indonesia. Available at: http://www.ampl.or.id/pdf/unicef/Profil_Sani tasi_Sekolah_Tahun_2017.pdf.

Kusumawardani, N. et al. (2015) Penelitian Kualitatif di Bidang Kesehatan, PT Kanisius. PT Kanisius.

Lewis, H. E. et al. (2018) 'Effect of a school-based hygiene behavior change campaign on handwashing with soap in Bihar, India: Cluster-randomized trial', American Journal of Tropical Medicine and Hygiene, 99(4), pp. 924-933. doi: 10.4269/ajtmh.18-0187.

Lina, H. P. (2016) 'Perilaku Hidup Bersih dan Sehat (PHBS) Siswa di 42 Korong Gadang Kecamatan Kuranji Padang', Jurnal Promkes, Vol 4 no 1.

Maanen, P. Van et al. (2016) Prioritizing pupils education, health and well-being. WHO Regional Office for Europe.
Majorin, F. et al. (2014) 'Child Feces Disposal Practices in Rural Orissa: A Cross Sectional Study', 9(2), pp. 1-7. doi: 10.1371/journal.pone.0089551.

Murwanto, B. (2017) 'Faktor Perilaku Cuci Tangan Pakai Sabun ( CTPS ) di SMP', Jurnal Kesehatan, VIII, pp. 269-276. Available at: https://ejurnal.poltekkestjk.ac.id/index.php/JK/article/download/445/ 469.

Nurhalina, Suratno and Marchel, J. (2017) 'Nurhalina, Suratno dan Jarot Marchel: Pembinaan dan Pendampingan Perilaku Hidup Bersih dan Sehat (PHBS) ...', PengabdianMu, Volume 2, pp. 37-46. Available at: http://jurnal.umpalangkaraya.ac.id/ejurnal/pg bmu.

Nurhayu, M. A. et al. (2018) 'Pelaksanaan Trias Usaha Kesehatan Sekolah pada Tingkat Sekolah Dasar di Wilayah Kecamatan Tembalang Kota Semarang', 6, pp. 770-779.

Nutland, W. and Cragg, L. (2015) Health Promotion Practice. 2nd edn. Edited by W. Nutland and L. Cragg. England: Open University Press.

Palinkas, L. A. et al. (2016) 'Purposeful sampling for qualitative data collection and analysis in mixed method implementation research', Adm Policy Ment Health, 42(5), pp. 533-544. doi: 10.1007/s10488-013-0528-y.Purposeful.

Purwandari, R., Ardiana, A. and Wantiyah (2015) 'Hubungan antara perilaku mencuci tangan dengan insiden diare pada anak usia sekolah di kabupaten jember', Jurnal Keperawatan, 4, pp. 122-130. Available at: http://ejournal.umm.ac.id/index.php/keperaw atan/article/view/2362.

Susilowati, D. (2017) 'Kebijakan Penanggulangan Anak Jalanan di Kota Malang', SENASPRO.

UNICEF (2013) Committing to Child Survival: A Promise Renewed Progress Report 2013.

Wolf, J., Hunter, Paul R., et al. (2018) 'Impact of drinking water, sanitation and handwashing with soap on childhood diarrhoeal disease: updated meta-analysis and meta-regression', Tropical Medicine and International Health, 23(5), pp. 508-525. doi: 10.1111/tmi.13051.

World Health Organization (2013) Ending Preventable Child Deaths from Pneumonia and Diarrhoea by 2025 The integrated Global Action Plan for Pneumonia and Diarrhoea ( $G A P P D$ ). Geneva: WHO. Available at: https://apps.who.int/iris/bitstream/handle/106 65/79200/9789241505239_eng.pdf?sequence $=1$.

World Health Organization (2016) Core questions and indicators for monitoring WASH in Schools in the Sustainable Development Goals. Geneva. 